\section{African rift in Kyoto}

\section{London}

NEXT year's meeting of the Convention on International Trade in Endangered Species (CITES) promises to be a stormy affair, now that a CITES-appointed expert panel has endorsed a South African plan to begin a controlled trade in ivory from that country. If the 112 nations that have signed the convention agree with the panel's assessment when they meet next March in Kyoto, Japan, the international trade in ivory will be reopened, less than four years after the CITES signatories decided that a complete ban was needed to preserve Africa's rapidly dwindling elephant populations (see Nature 341, 555; 1989).

Many observers expect South Africa's request to be rejected, but the debate surrounding the plan - and, more significantly, similar requests from five other southern African countries now being examined by CITES experts (see Nature 351, 7; 2 May 1991) - will bring to the surface deep divisions among the African nations over how best to conserve their elephant populations.

In one camp stand the southern African nations requesting that their elephant populations be removed from Appendix 1 of CITES, which lists species (and populations within species) in which no trade is permitted. This group, comprising Botswana, Zimbabwe, Malawi, Namibia and Zambia, points out that its elephant populations are not endangered, and argues that the revenue gained from sales of ivory can help conservation by financing anti-poaching patrols and providing economic rewards for local people (who otherwise have no good reason to support elephant conservation, as the animals often compete for valuable agricultural land).

Opposing them is another group, including Kenya, Tanzania, Ghana and Zaire, which admit that they do not have the resources to control poaching, and so want the ivory trade to stay banned until Western nations provide the necessary financial aid for them to manage their elephant populations effectively. The expected clash between the two groups in Kyoto is acutely embarrassing to black African governments, which like to show a united front in international negotiations involving the developed world (although politically isolated South Africa is not bothered by it at all).

In 1989, when all African elephant populations were moved onto Appendix 1, most CITES signatories decided that the trade had to be banned entirely, despite the reasonable claim from several southern African countries that their wildlife management practices were sufficiently sound to allow a controlled trade without endangering their elephant populations. Given that many other African countries were unable to stamp out serious problems with poaching, the 1989 CITES meeting in Lausanne, Switzerland, decided that allowing any legal trade would provide a cover through which illegal traders could 'launder' their poached ivory. The decision came after a decade in which the total population of African elephants dropped from 1.3 million to a mere 650,000 .

This approach has been successful, now that the two main importers of ivory, Japan and Hong Kong (represented within CITES by Britain), have accepted the CITES decision, slashing the demand for ivory. The trade has withered, and poaching has been reduced - by a factor of almost 100 in Kenya, for example.

Many conservationists and ecologists believe the same objections to a legal ivory trade that convinced the CITES signatories in 1989 also hold today, and say that the ban's success should not be jeopardized by its relaxation (see Nature 351, 265; 23 May 1991). So why did the fivemember CITES panel disagree, when confronted with the South African proposal?

One important factor is the advent of two new techniques to identify the origin of particular tusks. Before the trade was banned, tusks were often identified only by serial numbers written in supposedly permanent felt-tip pen. Not surprisingly, poachers found it relatively easy to disguise the source of their tusks. But the new South African plan includes the marking of tusks with tamper-proof adhesive holograms, developed by the South African Council for Scientific and Industrial Research; the holograms disintegrate when removed and will be extremely difficult to forge. The plan also relies on a new technique, first described in Nature (346, 744; 1990), which measures the isotope ratios of carbon, nitrogen and strontium in ivory

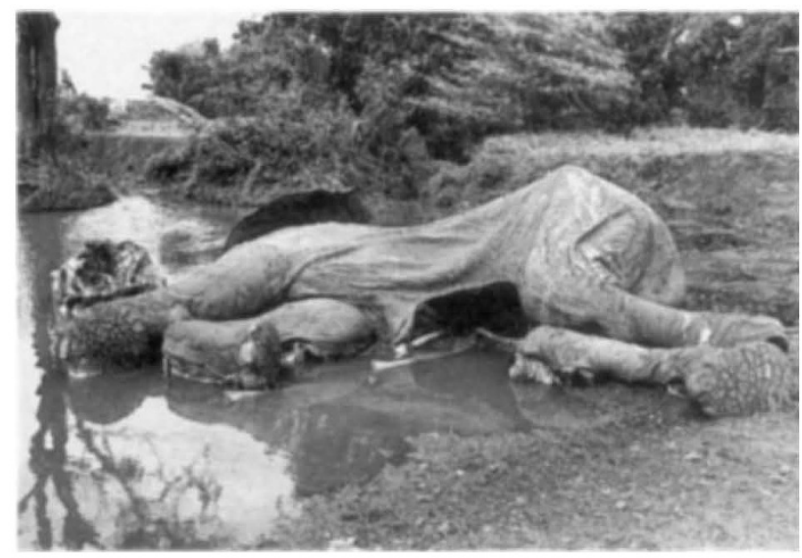

Will removing the ivory ban lead to more of this? samples, and which can be used to determine the particular region from which an individual tusk originated.

In its report, released earlier this month, the CITES panel says that these new developments will reduce the chances of laundering illegal ivory through a CITESsanctioned South African trade and concludes that South Africa's elephants could be moved onto Appendix 2 of CITES, allowing a carefully controlled trade in South African ivory, without increasing the threat of poaching.

But despite the CITES panel's verdict, the plans to resume a limited trade can expect a rough ride in Kyoto, both from the African states that oppose their neighbours' approach and from many developed nations. Steve Cobb, from the Environment and Development Group in Oxford, which has helped many of the African nations to produce elephant conservation plans, points out that the stable wildlife management policies in those countries now asking for a resumption of the ivory trade may not last. In Zimbabwe, for example, he expects the importance of conservation in land-use policy to "drop below the horizon" in the coming years as a brewing row over land ownership comes to a head: more than a decade after Robert Mugabe came to power, little of Zimbabwe's land has come into the hands of the black majority. Also, many of the African states with which Cobb has been collaborating want to use his conservation plans to attract aid from agencies such as the World Bank. Until these deals have been negotiated, most of these countries want the ivory trade to stay banned.

Most conservation experts are unwilling to forecast the outcome of Kyoto meeting. "Who can predict what will happen when you put 112 countries in one room?" asks Jonathan Barzdo, a member of the panel that examined the South African plan. But if the southern African states fail in their attempt to obtain CITES approval to trade in ivory, they still have the option to try to sell their ivory anyway. All six nations entered a reservation to the Appendix 1 listing after the 1989 meeting. Although none of the southern African states are trading in ivory at the moment, the reservations enable them to ignore the CITES ban. The only problem will be finding importers for their tusks. "Nothing has been decided," says Herman Grove, from the South African Department of Environment Affairs, "but the possibility for trade is still fairly limited." Japan and Hong Kong have no reservation against the ivory trade ban, and it would take several years for other countries that have not signed CITES to expand their ivory working industries and create a significant demand.

Peter Aldhous 